\title{
Typical conservation problems of polychrome wooden sculptures in Slovenia
}

\author{
Martina Vuga ${ }^{1, *}$ \\ Miladi Makuc Semion² \\ ${ }^{1}$ National Gallery of Slovenia, Puharjeva ulica 9, 1000 Ljubljana, Slovenia \\ ${ }^{2}$ University of Ljubljana, Academy of Fine Arts and Design, Erjavčeva cesta 23, 1000 Ljubljana, Slovenia \\ *martina_vuga@ng-slo.si
}

\begin{abstract}
The Slovene ethnic territory lies at the contact of Italian and German cultural influences, which can also be traced in gilded works of art. The majority of wooden Gothic art heritage has been lost for good, but a great number of wooden "golden altars" from the 17th century and large 18th century baroque altarpieces with outstanding sculptures survive. Conservators-restorers face great problems resulting from repeated restoration interventions of a great deal of these works of art. The paper describes a recent treatment undertaken at the National Gallery of Slovenia of an 18th century water gilded sculpture from no more existing altar, which was subsequently and typically overpainted several times. The case study is used to illustrate the problems encountered in overpaint removal from gilded areas.
\end{abstract}

Problemas de conservação de esculturas em madeira policromada na Eslovénia

\section{Resumo}

O território esloveno está directamente exposto às influências culturais italianas e alemãs, que também podem ser detectadas nas obras de arte douradas. A maior parte do património artístico gótico em madeira perdeu-se irremediavelmente, mas muitos altares barrocos dourados, dos séculos XVII e XVIII, sobreviveram com esculturas notáveis. Os conservadores-restauradores enfrentam grandes problemas devido às repetidas intervenções de restauro em muitas dessas obras. Este artigo descreve o tratamento recente, efectuado na Galeria Nacional da Eslovénia, de uma escultura do século XVIII, dourada a água, de um altar que já não existe, que, como é habitual, foi repintada diversas vezes. Este caso ilustra os problemas colocados pela remoção de repintes de motivos dourados.

\section{Keywords}

Conservation

Wooden sculpture

Gilding

Overpainting removal

\section{Palavras-chave}

Conservação

Escultura em madeira

Douramento

Remoção de repintes 


\section{A glance at the history of wooden sculpture in Slovenia}

The Slovenian ethnic territory lies at the contact of Italian and German cultural influences, which can also be observed in the works of art. Wood as a material for making sculptures and altarpieces is, in fact, self-evident, as more than a half of Slovenian territory is covered with forests. When we speak of gilded wooden sculpture we have especially sacred or religious art in mind, because only a few gilded secular objects have been preserved.

Wooden works of art dating back to the Romanesque period are extremely rare. Unfortunately, also the majority of Gothic wooden sculptures and wing altars are lost forever - some of them because the period of the Reformation was opposed to decorating religious places, and others because of later changes in the liturgy rules and instructions of the Council of Trent. Individual sculptures are now incorporated in new ensembles or are kept in museums.

Hundreds of "golden altars" which replaced the narrative role of Gothic frescoes in the 17th century are the result of a planned revival of the Catholic Church after the era of Ottoman incursions and the Reformation period. The name "golden altar" originates in the popular naming because of its extensive gilding (Figure 1). Art historian Milan Železnik identified four major groups of altarpieces that were developed in the course of the 17th century; they differ in the structure of the retables, in the ground plan, and especially in the type of carved decoration and the colour impression of the whole altarpiece [1]. The altar architectural structures/retables were made of spruce (Picea abies) or fir (Abies alba), most often in the form of a monstrance which completely stands on the altar mensa. Due to a poor financial situation in some parishes, bare wooden altarpieces were mounted in churches waiting for long years to be painted and gilded [2]. Sculptures and ornamental elements were carved almost always from linden wood (Tilia cordata, Tilia platyphyllos) which is very suitable for carving because of its compact structure. The artistic quality of sculptures varies from awkward folk shapes to masterpieces. The surface of draperies and applied carved ornaments were water gilded; silver gilding was regularly covered with red and green, rarely blue, glazes. Silver leaves are often oxidised. Ornaments are sometimes made of unusual materials, such as gilded paper stars, coloured coatings sprinkled with crushed glass or even metal particles. Originally, the architectural structures of altarpieces were painted from uniformly black to naive imaginary marble patterns in bright colours. The niches were painted blue, usually with smalt.

Large baroque altarpieces of the following 18th century differ in construction and especially in size. The architectural structures of the retables, made of spruce or fir, were firmly clamped between the walls of the presbytery and they are true masterpieces of carpentry

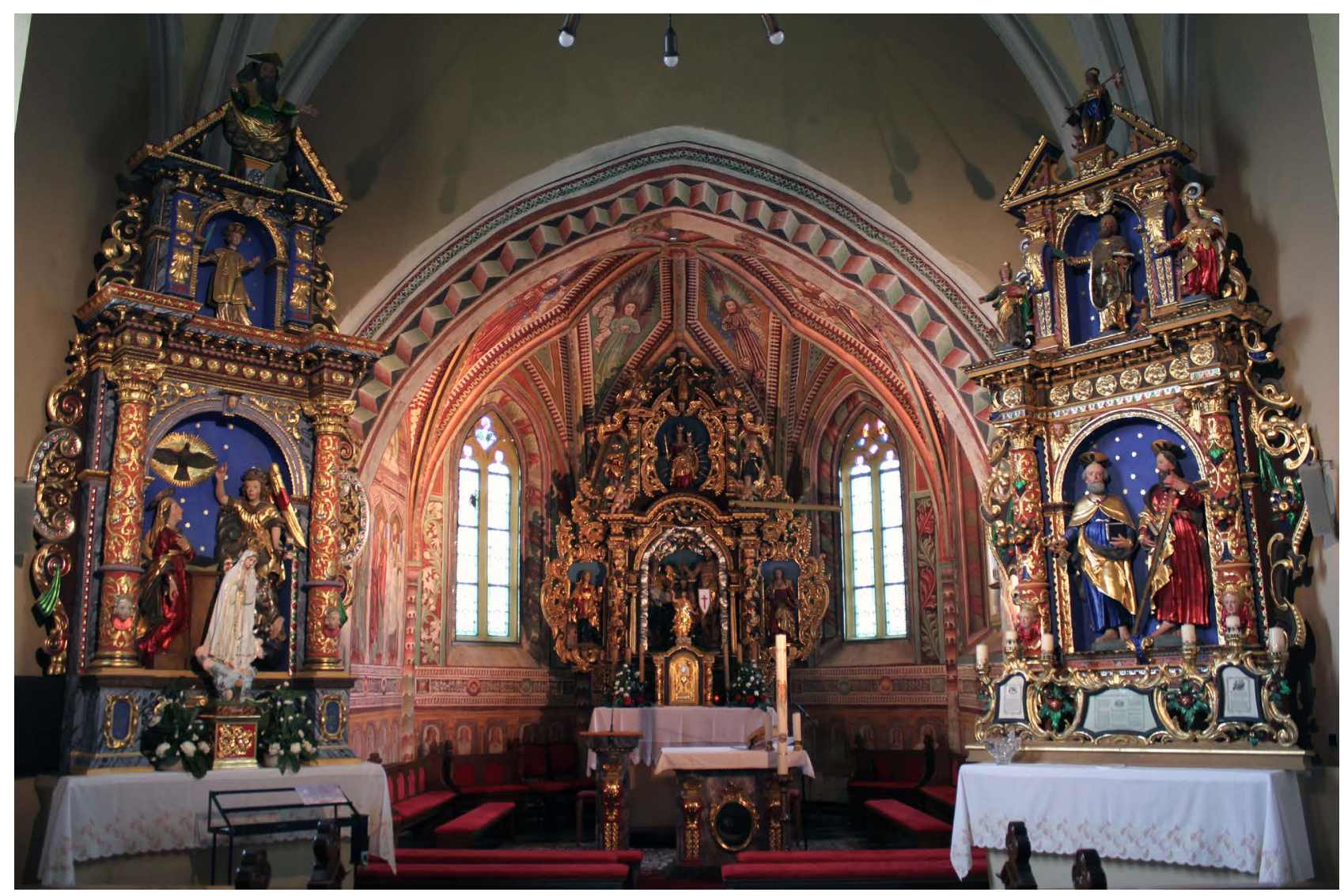

Figure 1. Interior of Parish Church of St. John the Evangelist, Suha pri Škofji Loki, with "golden altars": main altar in form of a monstrance (1672) and older collateral altarpieces (1643 and 1652), polychromed and gilded wood. Photo: Miladi Makuc Semion. 
with purpose-built platforms which enable climbing and walking on these structures (Figure 2). Restoration is only possible in situ. The architectural parts of the retables were originally painted with an imitation of marble but were later overpainted several times. In proportion to the overall structure, the 18th century sculptures are big and often over life-size. They are made of linden wood from a single tree trunk and only the protruding parts, such as arms and billowing draperies, have been added. The sculptures are worked only to two-thirds at the front, whereas their back sides are hollowed out. Original materials and gilding techniques are similar to those identified in other countries: burnished water gilding on the outer surfaces of clothing and matt on the inner surfaces, silvering with coloured glazes, engraving, punching, sgraffito, etc. Preparation layers are rather thick especially on gilded areas. Bole is applied in two layers yellow first and then red. For the red bole it was common to use egg white as a binder.

The production of woodcarving workshops in the second half of the19th century was so extensive that it exceeded the needs and demand. This resulted in unnecessary replacing of church furnishings, and the newly made structures often included sculptures from baroque altarpieces [3]. In the 19th century, various neostyles came into fashion, all of which were not really fond of gilding. Due to the new lifestyles and aesthetics, carving and gilding died out in the 20th century, so that we are now witnessing the disappearance of such vocations hence the disappearance of knowledge and skills.

\section{Conservation-restoration issues}

Today, conservator-restorers are faced with objects that have been countless times reworked and modified and have also been severely damaged due to different factors. Modern conservation and restoration principles oblige us to preserve the original materials and intervene as little as possible, but numerous owners want their sculptures to be "just" re-painted or re-gilded. They have no interest for a thorough investigation and documentation. It is often difficult to persuade people that the original painting and gilding are an integral part of the sculpture and should be retained, although no longer shiny and in bright colours.

The reason why a sculpture's polychromy are often ignored even by some conservator-restorers and art historians lies primarily in the very nature of the sculpture - if you take the colour off the sculpture, the shape still remains. Hence, we often find sculptures cleaned to the bare wood. On the other hand, some damaged sculptures were disfigured by new thick layers of different filling material and preparation. Preservation and reconstruction of polychromy require an in-depth knowledge of technology, skills and understanding of art.

Wood is an anisotropic material and the changes in relative humidity make it behave quite differently from the paint layers. The result is that an entire layer, which can be more than a millimetre thick, starts flaking and falls off. Hence we do not have to deal only with a damaged colour appearance, but also with a spoilt shape. Additional changes of shape are the result of wood insects' attacks. Linden wood is very susceptible to attacks by wood-boring beetles, which can destroy the inside of the sculptures and turn it into dust while the shell of gilding gives the appearance of a solid sculpture. But very little is needed for such a sculpture to collapse. In such cases, the preservation of gilding and polychromy is a real challenge.

The original gilding was also very often unreasonably coated with bronze powder paint or re-gilded with real gold or its imitation - usually on oil mordant although the original was water-gilded. Also the overpainting of gilded sculptures was common throughout history. Quite wellpreserved gilding is often hidden underneath paint layers, and it has been preserved - ironically - just because of the repaint. At the end of the 18th century gilding became a sign of waste, and in 1784 Emperor Joseph II issued a decree that allowed gilding only the edges of the garments of new figures, and consequently also existent figures that had been originally gilded were now painted white [3].

So we see that the problem of polychrome wooden sculpture is multi-faceted. Ignorance and indifference of the owners and the self-proclaimed "restorers"- people who don't have the necessary knowledge and training, promoted by the general climate tending towards entrepreneurship, too often lead to grotesque results, even fatal for the artworks. A conservator-restorer always finds satisfaction in the unveiling of the original layers of gilding and polychromy, since this contributes a missing particle to the studies on technical art history.

\section{Case study: removal of overpainting from gilded areas of a wooden sculpture}

\section{Introduction}

The presented case study is an example of a recently treated 18th century sculpture of Saint John the Evangelist from the National Gallery of Slovenia. The sculpture was separated from its original retable in the past and later became a part of a museum collection. The progressive changing of surfaces in the past has resulted in the alteration of original colours. The sculpture, originally water gilded, was subsequently overpainted several times. In conservation terms, the structure of the sculpture was good, but the surface was adulterated (Figure 3).

Conservation-restoration treatment began in September 2012 with the goal of displaying the sculpture in an Extended Permanent Collection which was scheduled to open in 2015 after the renovation of the old palace of the National Gallery. The key goals of the treatment were to achieve the appearance of the surface that would reflect the sculpture's original look and to preserve the original material to the greatest possible extent. 


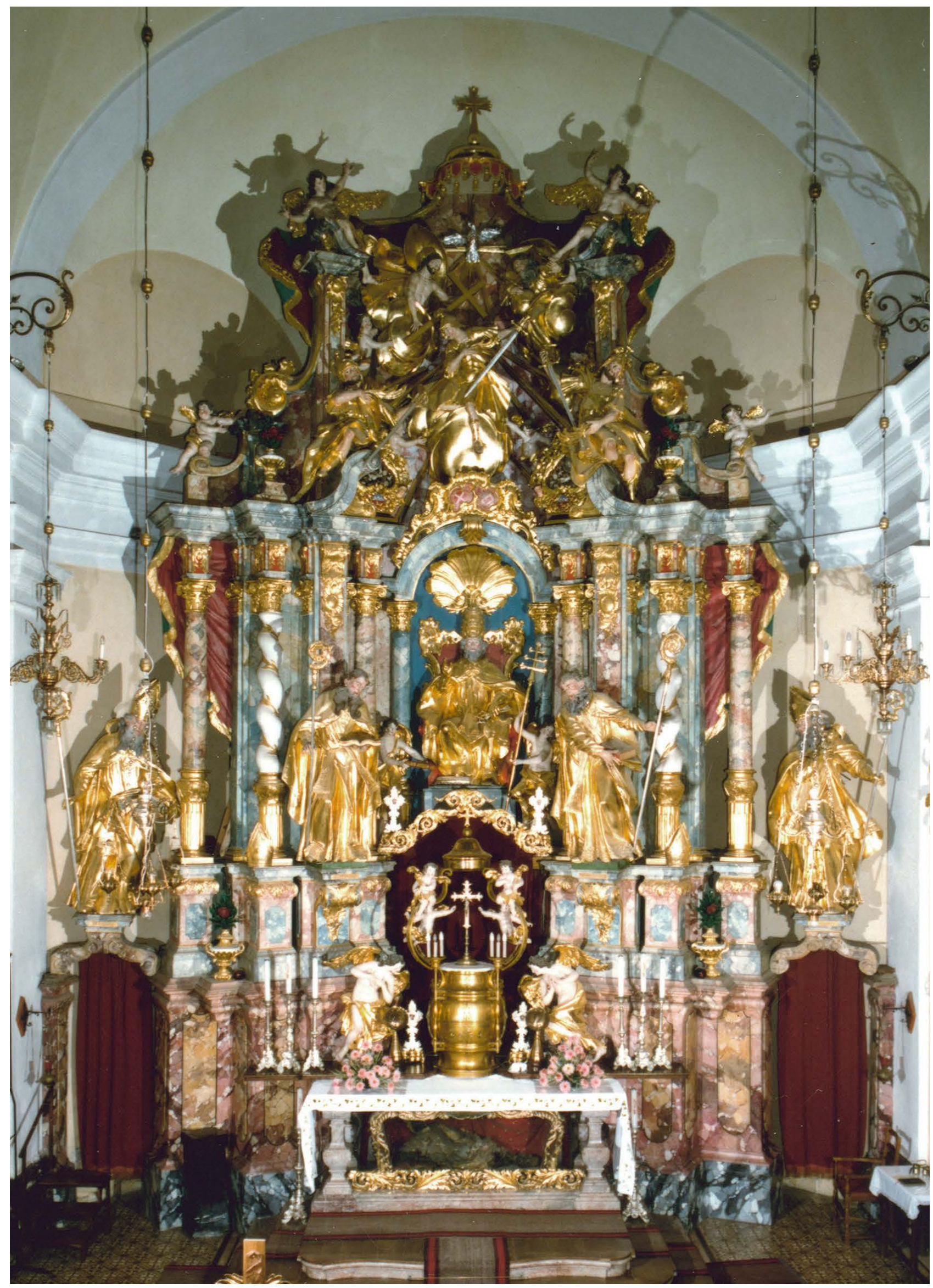

Figure 2. Main altarpiece (1758) in the Parish church of St. Peter, Komenda, made by Janez Gabric according to the design by Franc Jelovšek, polychromed and gilded wood. Photo: Archive IPCHS RC. 
The treatment involved examination, documentation and the procedures followed the removal of numerous layers of overpainting; this was the first step in which the main effort was concentrated. The work was done using different cleaning systems - by mechanical and chemical means under magnification. Besides the procedures followed in overpainting removal, the results of cross section analyses are also described.

\section{History}

The polychrome wooden sculpture with the dimensions $160 \times 102 \times 46 \mathrm{~cm}$, once owned by St. Peter's Parish Church in Ljubljana and now belonging to the holdings of the National Gallery of Slovenia (inv. no.:
NG P 199), dates from the 1770s. It is attributed to the sculptor Heinrich Michael Löhr (1700-1761) who lived in Ljubljana where he ran his own workshop. Judging from other items in the oeuvre of the same artist, it has been assumed that the garments of the Saint were originally gilded.

\section{Preliminary examination}

During the first examination most of the damage was detected on the wooden support and paint layer of the bottom part of the figure and the pedestal, so it was concluded that the sculpture had been exposed to standing and/or flowing water. It was most probably moved from the retable in the church interior to an
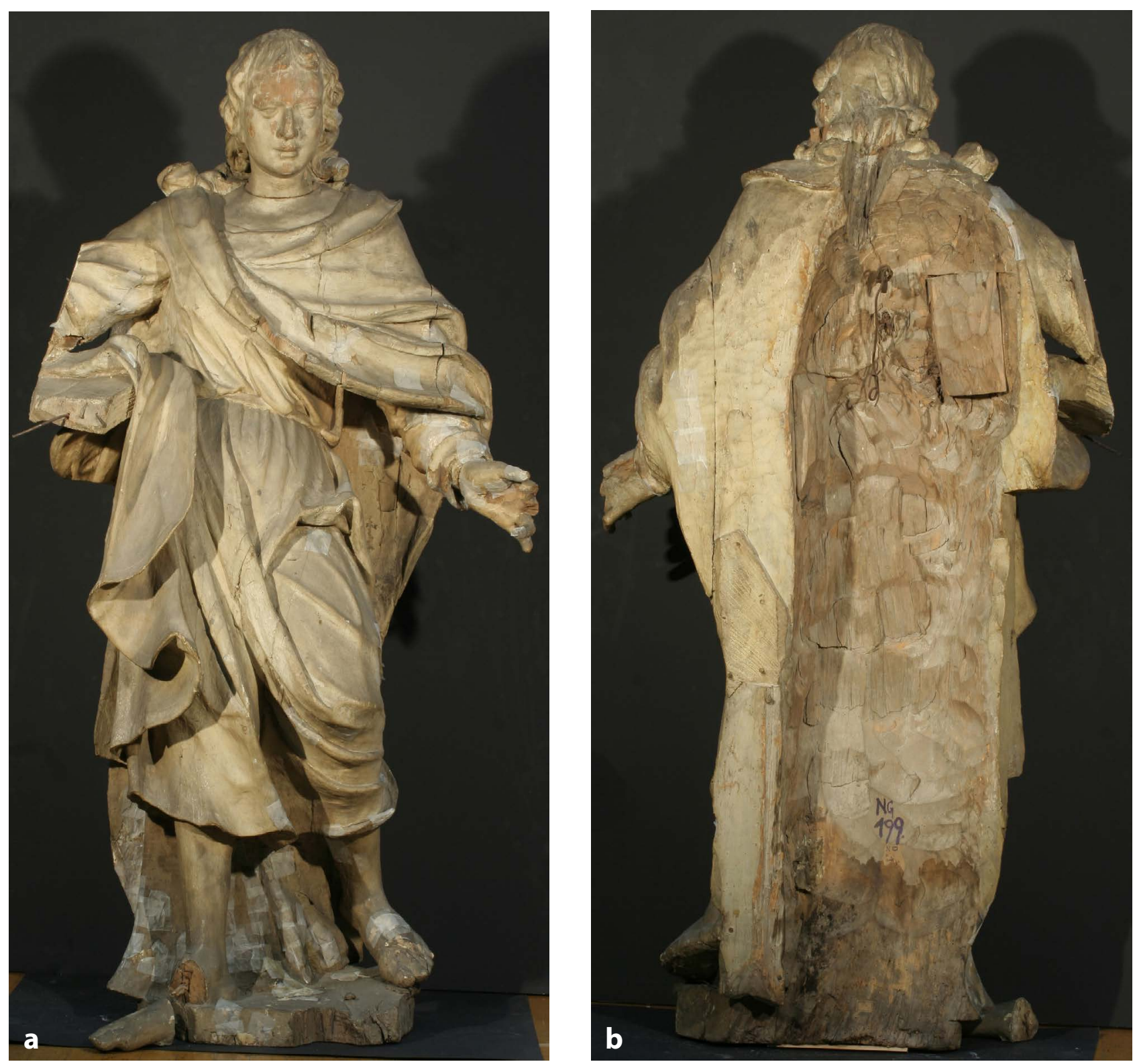

Figure 3. Saint John the Evangelist, attributed to Heinrich Michael Löhr, 18th century. Polychromed and gilded wood; h. $160 \mathrm{~cm}$; National Gallery of Slovenia NG P 199. The sculpture is composed of several constituent elements; the main part of the figure was carved from a single block of wood and its back side is hollowed out. In the past sculpture was painted in greyish white. Before treatment. Photo: Vuga Martina, National Gallery of Slovenia. 

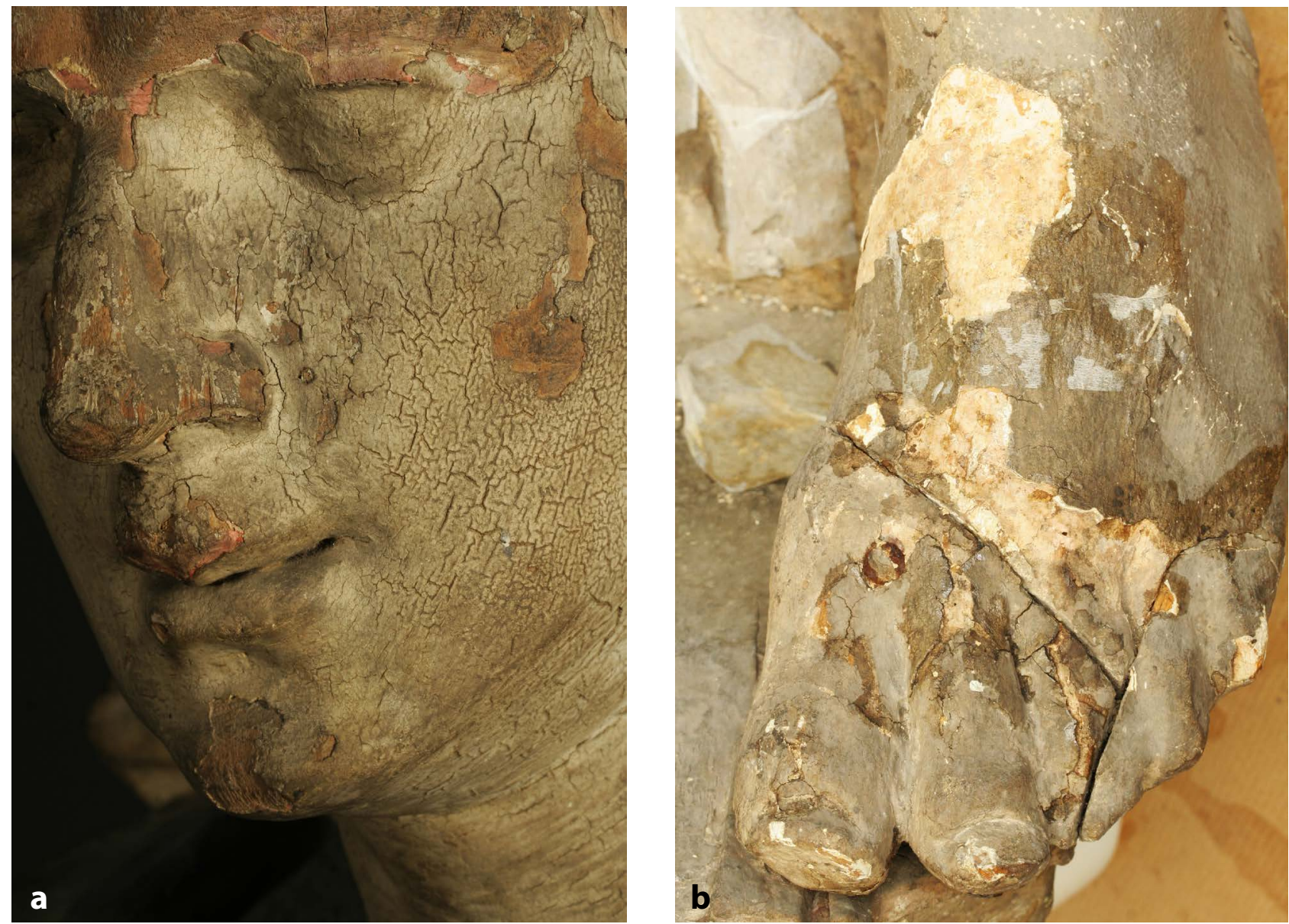

Figure 4. Details of the Saint John the Evangelist. Condition of the ground and paint layers before treatment. Overpaintings delaminated, fallen off in some isolated smaller areas, and coloured layers were visible underneath e.g. above the upper lip and the nose, carnation on the foot. Photo: Vuga Martina, National Gallery of Slovenia.

outside position, maybe a niche on the facade. The most recent greyish white colour, possibly as an imitation of marble stone had presumably been put on the sculpture before moving it outside (Figure 3). These overpaintings delaminated, fell off in some isolated smaller areas, and coloured layers were visible underneath, e.g. just above the upper lip, on the neck, the nod of a cloak and on the hair (Figure 4).

\section{Description of the sculpture's construction}

The sculpture is composed of at least sixteen pieces of wood. The main part of the figure was carved from a single block of wood and its back side is hollowed out (Figure 3).

Several removable/separate parts were added. Some of these are bigger, e.g. the head, the Saint's right arm with a part of the book, the left arm with a part of the garment, the right and left hands, and the left foot, whereas some parts are smaller, such as fingers or finger tips, etc. (Figure 5).

The constituent parts were originally glued and held together probably only by wooden dowels. Nails were used for fixing elements during previous interventions. A complete disassembly prior and also during the treatment was not possible because of a great number of deeply hammered nails.

\section{Condition}

\section{Wooden support}

Wood species were not identified. The wooden support of the body was generally in good condition. Some of the constituent removable elements had been detached but were preserved, but some (important) pieces, e.g. fingers on the left hand, parts of the folds of the garment, part of the book and of the pedestal, were missing/lost. Some of the joints of the removable parts were loose and apart and some elements were completely separated from the main piece. Some damage from insect activity was present, but just a few inactive exit holes of wood-boring insects were found on the back of the sculpture, most of them on the upper part. The structure of the wood was not affected, so there was no need for consolidation.

There were some radial cracks filled with wooden wedges and fixed with nails in earlier interventions. 


\section{Ground layers}

The condition of the ground layer on the major part of the surface was acceptable as could be assumed from the generally acceptable condition of the paint layer. However, some extensive losses of the ground layer, together with the paint layer, had occurred. Most of the damage of the ground layer was found on the areas exposed to water: the forehead, the upper side of the book, the bottom part of the cloak behind the Saint's legs, the Saint's feet and the upper side of the pedestal. Additionally, there were some scattered losses, a couple of square centimetres large, on the cheeks, nose, upper lip and chin. Some cracking and lifting of gesso layer occurred especially above the loose joints (Figure 4).

\section{Paint layers}

There was a network of cracks on the major area of the paint layer, but there were also parts with no cracks (right arm with a cloak). The paint layer was greatly damaged on the parts exposed to standing water. The surface was covered with a heavy layer of grime that had accumulated over time (Figure 4).

Probing with a scalpel through the overpainted layers at different areas showed several subsequently added layers. This method suggested that the sculpture was originally not white but coloured and the garments were gilded. But apart from white layers, no original polychromy, gilding or ground layer could be found on the upper part of the body, on the outer part of the cloak just under the Saint's right arm and on the Saint's left thigh.

\section{Scientific examination}

\section{Analytical methods}

In order to identify clearly the layer structure, binders and pigments, originally and subsequently used, and to help us finding a safe way of removing all the added layers, cross-section samples were collected from several points of the sculpture.

Different analytical techniques were used. Optical microscopy was used in reflection mode using visible and ultraviolet radiation (Olympus BX60). For Fourier transformed infrared spectroscopy (FTIR), Spectrum 100 (Perkin Elmer) was used in attenuated total reflectance mode with a germanium crystal. All spectra were recorded with MTC detector within a range of 4000 and $600 \mathrm{~cm}^{-1}$ with a $4 \mathrm{~cm}^{-1}$ resolution. For a single spectrum 32 scans were obtained, using a diamond anvil compression cell. Raman spectra were collected with Horiba Jobin-Yvon LabRAM HR800 spectrometer coupled to an Olympus BXFM. Excitation laser with the wavelength of $784.5 \mathrm{~nm}$ was used. Spectrum was obtained with CCD detector with spectral resolution of $1 \mathrm{~cm}^{-1}$. Calibration was carried out with silicon crystal. Spectra were obtained in the range 50 $\mathrm{cm}^{-1}$ to $3200 \mathrm{~cm}^{-1}$.

Analyses were performed by the Natural Science Department of the Restoration Centre of the Institute for the Protection of the Cultural Heritage of Slovenia (IPCHS RC) where the samples and documentation on filters and times used are kept.

\section{Results [4]}

The wooden figure with its originally gilded garment was overpainted at least ten times. Analyses suggested
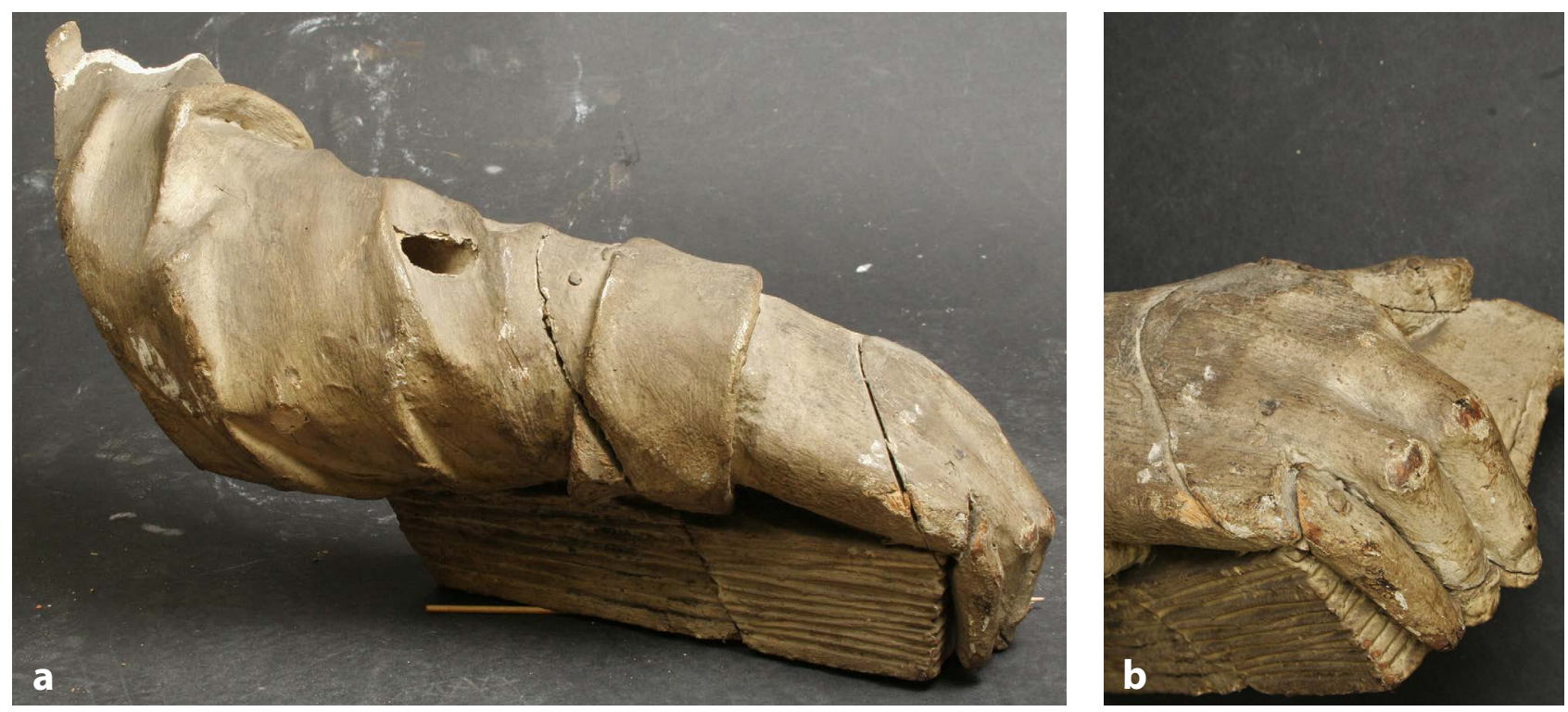

Figure 5. Details of the Saint John the Evangelist. Constituent elements of the sculpture: $a$ ) the Saint's right arm with a part of the book; $b$ ) hand with smaller separate elements of fingers and finger tips. Photo: Vuga Martina, National Gallery of Slovenia. 

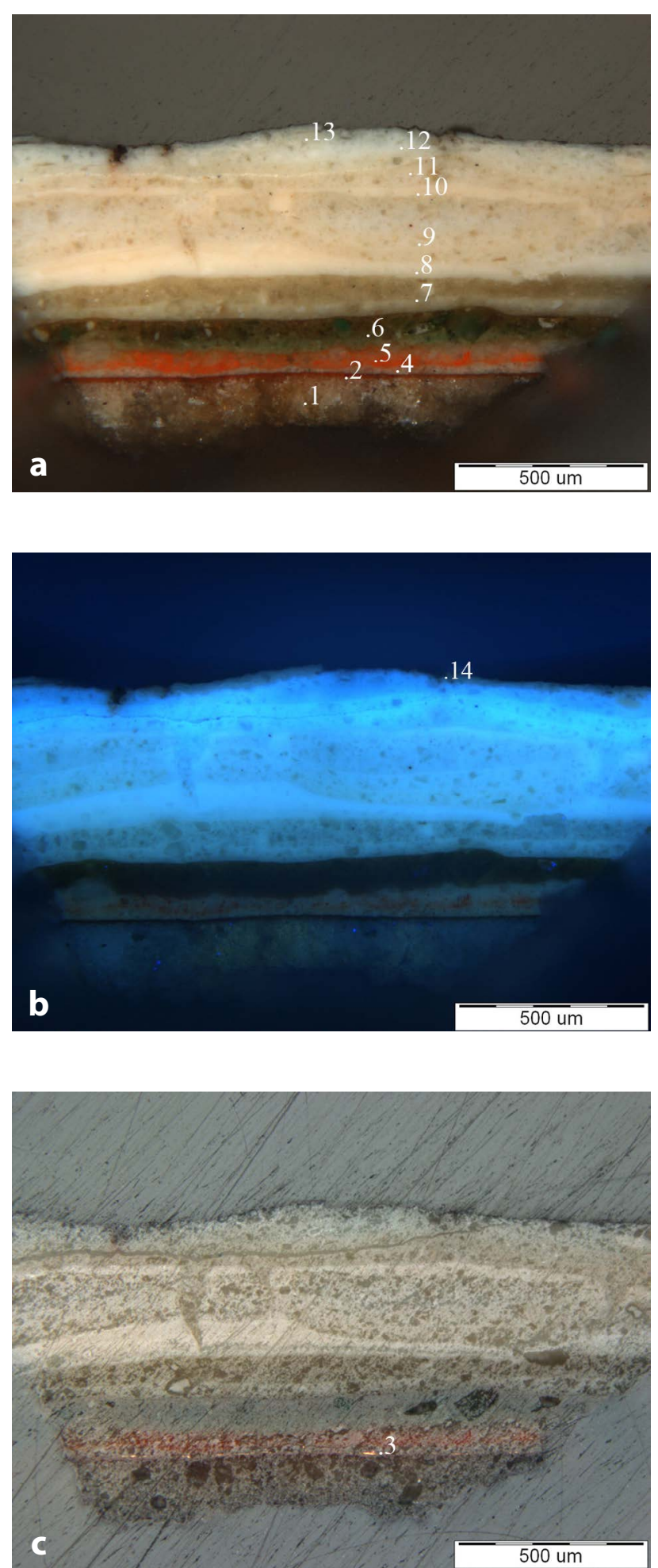

Figure 6. Cross section of paint stratigraphy from the lower part of the Saint's garment. Microphotograph at $10 \times$ magnification: a) visible light; $b$ ) ultraviolet radiation; $c$ ) polarized visible light. Photo: Kavkler Katja, IPCHS RC.

Cross section sample JEK 3: 1) Ground layer (calcium sulfate); 2) bole (red ochre); 3) gilding; 4) white (lead white, barium sulfate); 5) red (minium, lead white); 6) green, two layers (emerald green, lead white, barium sulfate, calcium carbonate, cinnabar); 7) translucent white; 8) white; 9) translucent white; 10) white-thin layer; 11) translucent white; 12) white; 13) white; 14) varnish, remains. at least ten layers of overpainting of which six to seven are uniformly greyish white and four are coloured. Two samples taken from the Saint's garment suggested water soluble ground layers composed of calcium sulphate and red bole used for the original water gilding (Figure 6).

Two samples taken from the outer part of the cloak showed a very similar structure to the one described above - a ground layer composed of calcium sulphate and the same number of overpaintings (four coloured and seven white).

A sample taken from the inner side of the cloak suggested that the green paint layer did not belong to the original because it was found inside the cracks of a silver layer which is a subsequent occurrence. Silver was laid on a red bole layer.

FTIR spectroscopic analyses detected oil as a binder in the original paint layers and protein probably making part of the original ground layer. Oil and wax were suggested as binders in most of the overpaint layers. There were some remains of a colophony varnish on the surface of some samples.

Raman spectroscopy suggested the presence of lead carboxylates. These are formed when a heavy metal, such as lead, reacts with free fatty acids present in the oil binder, and organic salts called soaps result. Lead pigments were used not only in all white overpainted layers, but also in coloured overpaintings and in the original colours (reds, greens). Repeatedly applied thick layers of white lead in oil binder formed an exceedingly hard crust.

\section{Treatment proposal and treatment}

The National Gallery's curators and conservators agreed to restore the surface of the sculpture to its original 18th century state. Overpaintings significantly changed the sculpture's appearance, so the key goals of the treatment were to achieve the appearance of the surface that would reflect the sculpture's original look and to preserve the original material to the greatest possible extent. Accordingly, the surface was to be cleaned selectively, and of all the cleaning procedures the removal of at least ten overpainted layers without damaging the gilded surface was the most demanding task.

Results gained from optical microscopy of cross section samples, FTIR and Raman microspectroscopy indicated the working directions to be followed in the treatment of the surfaces. The development of a cleaning system was based on the experimental work developed by Richard Wolbers and Paolo Cremonesi [5-8].

The testing of different methods, materials (detergents, solvents and gels in specific combination) and times of their application revealed that the white layers were not soluble in common neutral solvents either in free or gelled form, which could be explained by the formation of lead soaps. Developing a cleaning system was an ongoing process with the aim of understanding the working properties and chemical nature of the materials to be removed. 
Among the cleaning systems eventually employed were a buffer solution for surface cleaning, a gelled solvent system for swelling the white layers of overpainting and a solvent/detergent system for softening the coloured overpaintings.

\section{Surface cleaning}

Loose dust and dirt were brushed and vacuumed off the surface. Superficial grime was additionally removed from the painted surface by means of using a buffer solution $\mathrm{pH} 5.5$ prepared with ethylenediaminetetraacetic acid (EDTA).

\section{Overpaint removal}

Overpaint removal was done in two steps. The first step was the removal of white overpaint layers. It was possible to achieve the best results by mechanical means. A very limited swelling of white layers was reached after long-term applications of gelled ethanol. Six to seven white layers were relatively safely removed as they more or less easily delaminated from the last coloured layers of overpaint (Figures 7-8).

This step was very long-lasting, due to very thick and hard layers, highly varied modelling of the surface and various conservation condition of underneath layers.

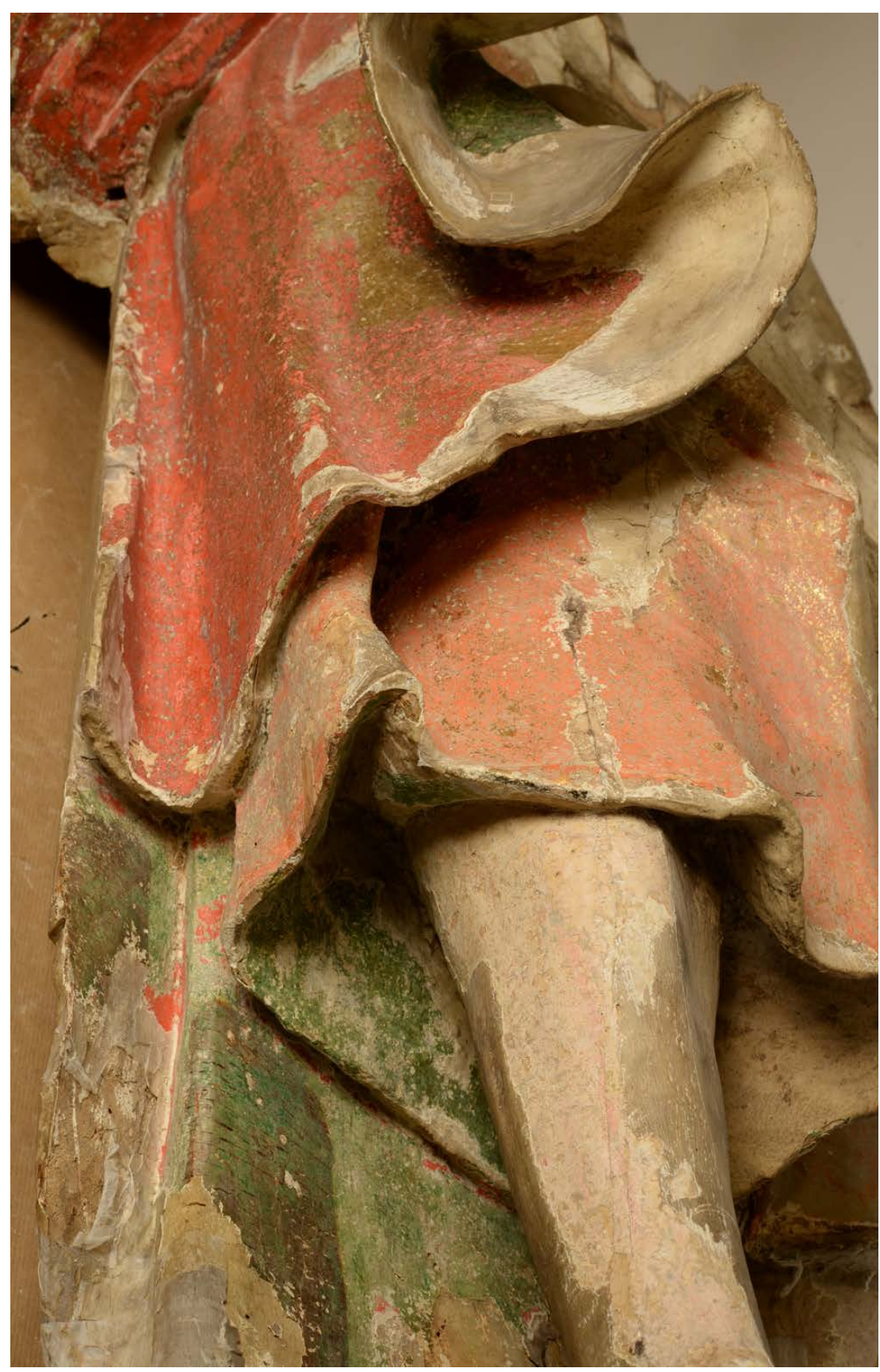

Figure 7. Detail from Saint John the Evangelist's garments after removal of white layers of overpainting. Photo: Vuga Martina, National Gallery of Slovenia. 

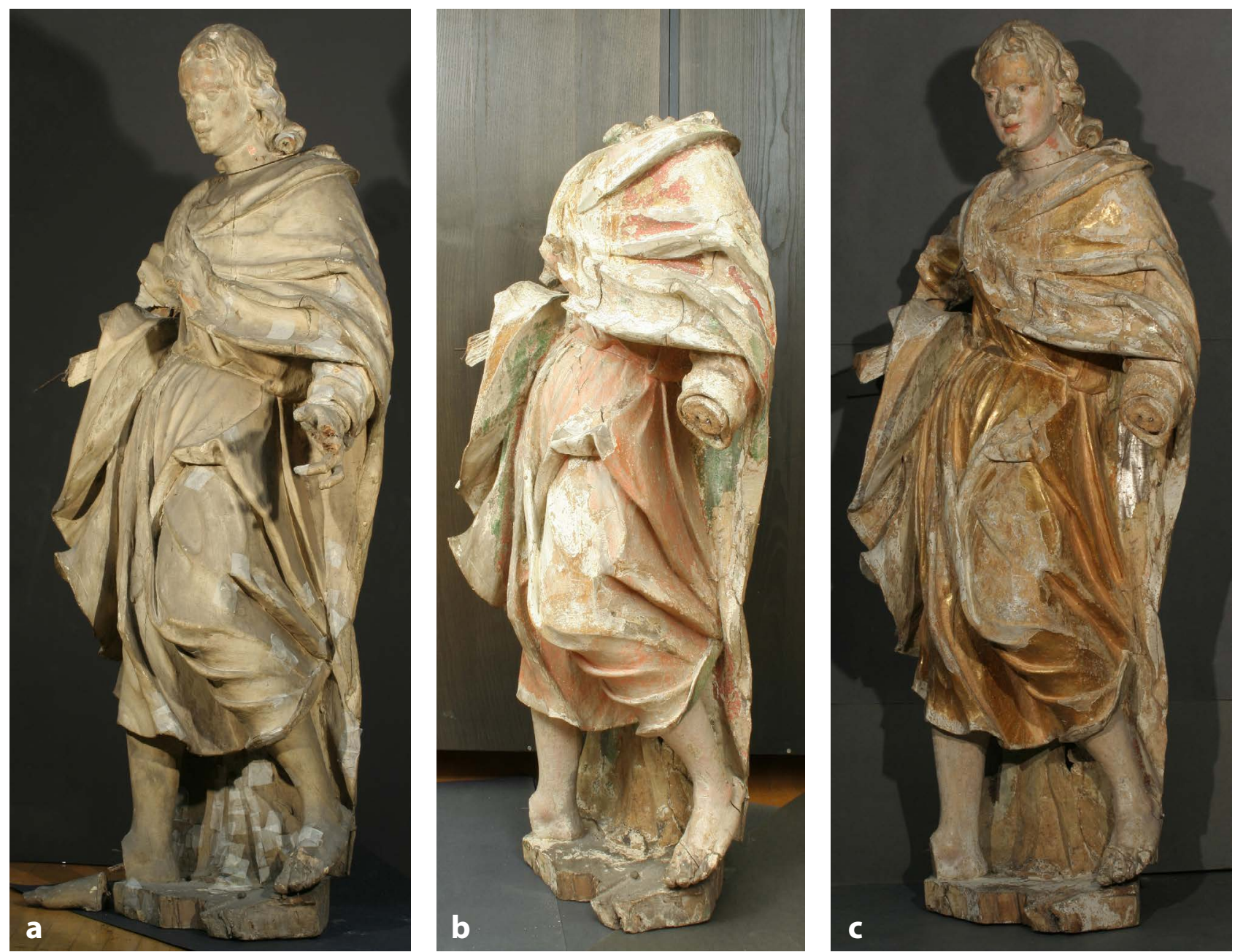

Figure 8. Saint John the Evangelist: $a$ ) before treatment; $b$ ) after removal of white overpaintings; $c$ ) after removal of coloured overpaintings. Gilded garment and gilded and silvered cloak. Photo: Vuga Martina, National Gallery of Slovenia.

Because the main action was still mechanical, in spite of the very careful work using Optivisor or a microscope, the procedure using a scalpel inevitably caused some damage in the parts where condition of the underneath layers was softer due to weakened damaged structure.

The complete removal of white layers revealed the extent of the damage (most probably) caused to the original ground and paint layers by water flow even before the sculpture was painted white. Those parts that had been safe(r) from flowing and/or standing water thanks to their position, e.g. under the folds of the garment, were well preserved, whereas the parts that had been exposed to water flow were destroyed: the ground and paint layers detached and were missing, e.g. the upper sides of the cloak. Even greater was the damage caused to the bottom part of the sculpture which is part of the pedestal where water probably stayed, e.g. behind the legs on the inner side of the cloak.

This intermediate phase presented the condition of the sculpture before it was overpainted white for the first time (Figure 8b). White overpaintings layers were applied also over the damaged parts, without a ground layer, directly on the wood.
Testing the removability of the remaining overpaints was repeated in the next step in order to find the safest way to reveal the gilded areas. Different solvent/ detergent systems were chosen to soften the surface of the overpaints. The greyish and red overpainted layers on water gilded garment were softened with a polar solvent surfactant gel made of benzyl alcohol, Ethomeen C25, Carbopol and a small quantity of water. Red and green overpaints on the outer part of the cloak were removed by using a non-polar solvent surfactant gel made of a mixture of solvents (Petrol $\mathrm{T}_{\mathrm{b}}$ 100-140 ${ }^{\circ} \mathrm{C}$, Shellsol A and Benzyl alcohol in ratio 4:1:0.8), Ethomeen $\mathrm{C} 12$, Carbopol and a few drops of water.

Applications of gel for 3 to 4 hours and covered with Melinex polyester film were repeated several times. The remains of overpaint were removed with using a scalpel and a solvent solution (Figure 9).

\section{Conclusion}

Based upon examination and tests locally made on the baroque sculpture in the National Gallery of Slovenia 

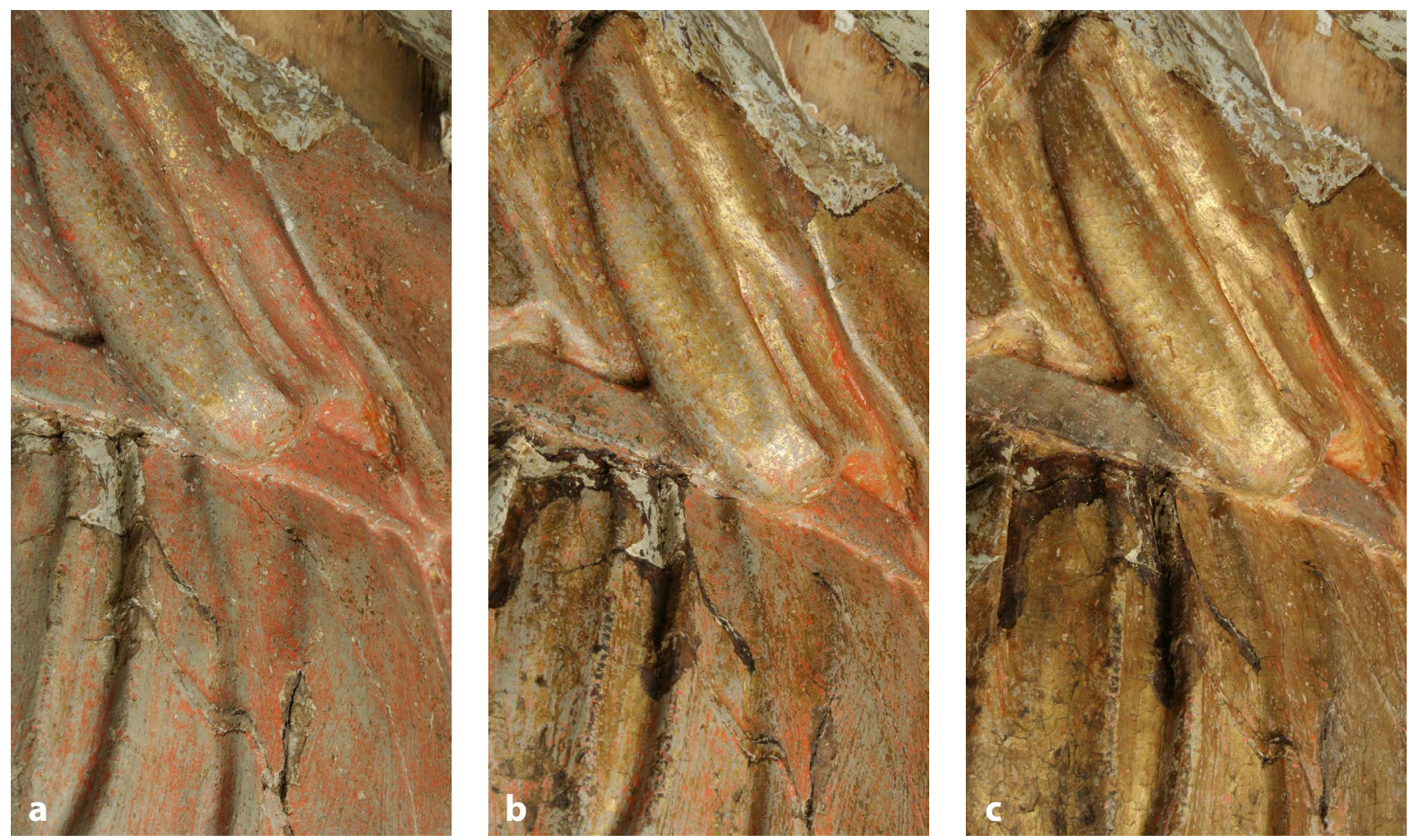

Figure 9. Detail from the Saint John the Evangelist's garment: gradual thinning and removal of coloured overpaintings revealed water gilded garment with silver belt. Photo: Vuga Martina, National Gallery of Slovenia.

before treatment the conservation condition of the most recent "marble" look was bad compare to the state of the underneath original layers which were rated acceptable. The most recent appearance was also so dramatically different from original that despite having in mind respect to the artwork history the option- restoring the sculpture to its original look seemed nearly the only option. By removing thick layers of overpaintings also the sculptor's fine modelling was revealed.

The goal of restoring the artwork to its original look is always a challenge in the case of multiple overpaintings. But cleaning and overpaint removal as its part have undergone considerable changes during the past decade. In this case following the most recent knowledge which allows more selectivity and gradual work, the task seemed accessible.

The first step was removing multiple white layers which formed extremely rigid and almost insoluble crust. As the main action of the removal using a scalpel was still mechanical it caused some unwanted damage to the original underneath layers on the parts of which conservation state was not so good.

In the next step, after removal of coloured overpaintings we have managed to get to the original gilding preserved on a large area (Figure 8c).

Extensive photographic documentation and material evidence in the form of stratigraphic samples is preserved for possible further study and to understand better this and related wooden sculptures.

Conservators-restorers in Slovenia deal with similar problems very often. Compare to the ones on the paintings the problems in the field of overpainting removal from gilded wooden sculptures are different and specific and this case has again revealed the need for further development and improvement of the systematic methodology.

\section{References}

1 Železnik, M., 'Osnovni vidiki za študij 'zlatih oltarjev' v Sloveniji', Zbornik za Umetnostno Zgodovino 4 (1957) 131182.

2 Lavrič, A., Ljubljanska Škofija V Vizitacijah 17. Stoletja. Vizitacije Kot Vir Za Umetnostno Zgodovino, Založba ZRC, Ljubljana (2007), http://zalozba.zrc-sazu.si/p/337 (accessed 2015-11-11).

3 Resman, B., Kiparstvo Poznega Baroka na Gorenjskem, Založba ZRC, Ljubljana (2006).

4 Kavkler, K.; Bešlagić, P., 'Narodna galerija, Heinrich Michael Löhr, Svetnik s knjigo v desnici (Sv. Janez Evangelist?): poročilo naravoslovnih preiskav', report, ZVKDS - Restavratorski Center, Ljubljana (2012).

5 Cremonesi, P.; Signorini, E., Un Approccio alla Pulitura dei Dipinti Mobili, Il Prato, Padova (2012).

6 Wolbers, R., Un Approccio Aquoso alla Pulitura dei Dipinti, $i$ Talenti, Il Prato, Padova (2004).

7 Wolbers, R., Cleaning Painted Surfaces. Aqueous Methods, Archetype Publications, London (2003).

8 Cremonesi, P. (ed.), Materiali Tradizionali ed Innovativi nella Pulitura dei Dipinti e delle Opere Policrome Mobili: Atti del Primo Congresso Internazionale Colore e Conservazione - Materiali e Metodi nel Restauro delle Opere Policrome Mobili, Il Prato, Padova (2002). 
Received: 2015-07-03

Revised: 2015-10-29

Accepted: 2015-11-11

Online: 2016-01-07

\section{(ब⿻ $\Theta$}

This work is licensed under the Creative Commons Attribution-NonCommercial-NoDerivatives 4.0 International License.

To view a copy of this license, visit http://creativecommons.org/licenses/by-nc-nd/4.0/deed.en. 